\title{
Distyly and variation in floral traits in natural populations of Psychotria ipecacuanha (Brot.) Stokes (Rubiaceae) ${ }^{1}$
}

\author{
ANA APARECIDA B. ROSSI ${ }^{2}$, LUIZ ORLANDO DE OLIVEIRA ${ }^{3,5}$ and MILENE F. VIEIRA ${ }^{4}$
}

(received: July 4, 2004; accepted: January 13, 2005)

\begin{abstract}
Distyly and variation in floral traits in natural populations of Psychotria ipecacuanha (Brot.) Stokes (Rubiaceae)). Psychotria ipecacuanha is a perennial, medicinal herb that grows in clusters in the understory of humid, shady areas of the Atlantic Rain Forest of southeastern Brazil. The present study characterized the variation in floral traits among 35 clusters from three natural populations of this plant species. Field observations showed that the clusters are isomorphic, that is, a given cluster will either set long-styled or short-styled flowers. Stigmas and anthers are reciprocally placed in each morph, a dimorphism characteristic of distyly. The populations are isoplethic, that is, a given population exhibits an equilibrium 1:1 ratio of floral morphs. Morphometric analyses revealed that anther length, stigma length, corolla diameter, and pollen grain diameter were consistently greater in short-styled flowers, regardless of the population investigated. Significant differences for floral traits in the short-styled morph were found among populations. Floral traits in the long-styled morph also showed some significant differences among populations, but not for stigma height and corolla length. Controlled pollinations carried out in natural populations showed that fruit production was higher after inter-morph pollination. Nevertheless, observations of pollen tube growth in style, and also fruit production after spontaneous self-pollination and intra-morph pollination, indicated partial intramorph compatibility in this plant species.
\end{abstract}

Key words - distyly, floral morphology, ipecac, medicinal plants, Psychotria ipecacuanha

RESUMO - (Distilia e variação das características florais em populações naturais de Psychotria ipecacuanha (Brot.) Stokes (Rubiaceae)). Psychotria ipecacuanha é uma espécie medicinal que se desenvolve em agregados perenes, denominados reboleiras, em áreas úmidas e sombrias no sub-bosque da Floresta Atlântica. O presente trabalho caracterizou a variação de atributos florais em 35 reboleiras de três populações naturais desta espécie. Observações de campo mostraram que as reboleiras são isomórficas, isto é, apresentam apenas uma forma floral (brevistila ou longistila). Estigmas e anteras estão posicionados reciprocamente em cada forma floral, um dimorfismo característico de distilia. As populações são isopléticas, isto é, apresentam razão equilibrada (1:1) entre as formas florais. Análises comparativas da morfometria floral revelaram que, independente da população investigada, as flores brevistilas apresentaram maiores médias de comprimento da antera, comprimento do estigma, diâmetro da corola e diâmetro do grão de pólen. Flores brevistilas apresentaram diferenças interpopulacionais significativas com relação aos atributos florais investigados. Flores da forma longistila também apresentaram diferenças interpopulacionais significativas, exceto quanto à altura dos estigmas e ao comprimento da corola. Polinizações controladas conduzidas em condições naturais mostraram que a produção de frutos foi maior após polinização legítima. Porém, observações de crescimento de tubos polínicos juntamente com a produção de frutos após autopolinização espontânea e polinização ilegítima sugerem que a espécie apresenta compatibilidade parcial intraforma.

Palavras-chave - distilia, morfologia floral, plantas medicinais, poaia, Psychotria ipecacuanha

\section{Introduction}

Heterostyly is a genetic polymorphism in which plant populations are composed of two (distyly) or three

1. Parte da Dissertação de Mestrado de A.A.B. Rossi, Universidade Federal de Viçosa, Departamento de Biologia Vegetal, 36570-000 Viçosa, MG, Brasil.

2. Universidade do Estado do Mato Grosso, Instituto de Ciências Naturais e Tecnológicas, Departamento de Ciências Biológicas, Campus Universitário de Alta Floresta, 78580-000 Alta Floresta, MT, Brasil.

3. Universidade Federal de Viçosa, Departamento de Bioquímica e Biologia Molecular, 36570-000 Viçosa, MG, Brasil.

4. Universidade Federal de Viçosa, Departamento de Biologia Vegetal, 36570-000 Viçosa, MG, Brasil.

5. Corresponding author: lorlando@ufv.br (tristyly) floral morphs. The morphs exhibit reciprocal positioning of anthers and stigmas (reciprocal herkogamy sensu Lloyd \& Webb 1992). Heterostyly is often linked to a sporophytically controlled, diallelic incompatibility system that, as a consequence, results in intramorph incompatibility (Barrett 1998). Positioning anthers and stigmas at similar locations within a flower increases the precision of pollen transfer between the short- and long-styled morphs since both sexual organs contact similar parts of the pollinator (Ganders 1979). Equilibrium morph ratio of 1:1 (isoplethy) should be reached in one generation in self-incompatible distylous populations because of the simple mode of inheritance and disassortative mating (Barrett 1992). On the other hand, the presence of self-compatibility or clonal propagation 
may induce a departure from the equilibrium ratio (anisoplethy) (Barrett 1992).

Besides reciprocal positioning of anthers and stigmas, the floral morphs of distylous species can display several ancillary characteristics, such as size of stigmatic lobes, size and number of pollen grains (Dulberger 1992), color of the floral organs (Wolfe 2001), and corolla tube length (Pailler \& Thompson 1997). However, several studies have shown that the morphological components of distyly can display some flexibility (Richards \& Koptur 1993, Faivre \& McDade 2001). Such studies took into consideration a great number of individuals from a number of populations and revealed that variation of floral traits associated with distyly may exhibit overlapping of values. Pailler \& Thompson (1997) and Faivre \& McDade (2001) found variations among flowers of the same individual, among individuals of the same population and among populations of the same species. As pointed out by Barrett \& Shore (1987), investigation in floral trait variation among populations may provide important information about the evolution, maintenance and/or loss of heterostyly.

Psychotria ipecacuanha (Brot.) Stokes (= Cephaelis ipecacuanha (Brot.) A. Rich.) is also known as "poaia" or "ipecac". This species is the botanical source of a drug that possesses recognized medicinal value. Ipecac drug has achieved worldwide usefulness because of its expectorant, amoebicide, and vomitive properties and remains official in pharmacopoeias of many countries around the world (Bruneton 1995). These pharmacological activities have been confirmed and the isoquinoline alkaloids emetine and cephaeline identified as the major bioactive compounds of ipecac (Bruneton 1995). Commercial harvesting of $P$. ipecacuanha occurred in southeast Brazil since the 18th century when the roots became a valuable trading good. Careless harvesting was a destructive procedure in view of the negligence in replanting after uprooting. Today, gathering of wild plants still provides most of the world demand for the drug. "Rio Ipecac" (harvested in southeast Brazil) has a better quality, but the drug is more scarce due to difficulties of wild gathering. A small fraction of this demand is supplied by commercial cultivation in India where domestication has been achieved with clones introduced from Brazil (Oliveira \& Martins 1998).

Remaining populations of $P$. ipecacuanha occur naturally in the understory of tropical forests from three widely discrete regions: a) Central America (e.g. Panama and Costa Rica) and adjacent parts of South America (e.g. Colombia); b) South-western part of the
Brazilian Amazon (states of Rondonia and Mato Grosso); and 3) Atlantic Forest along the Brazilian coast (mainly the states of Bahia, Espirito Santo, Rio de Janeiro, and Minas Gerais) (Veloso 1947, Assis \& Giulietti 1999). Although P. ipecacuanha occurs throughout an extensive area, the species has extremely low frequency under the forest canopy and is restricted to shady areas with very low levels of photosynthetic active radiation (Veloso 1947, Oliveira \& Martins 2002). Currently, the habitat of $P$. ipecacuanha within the Atlantic Forest has been disturbed by several anthropic activities, which directly threats the species with genetic erosion (Oliveira \& Martins 2002). Ipecac is listed as endangered by the state of Minas Gerais (Mendonça \& Lins 2000), the only Brazilian state within the geographic range of ipecac for which a plant conservation list has been published.

The individuals of $P$. ipecacuanha occur in tight clusters, which display circular or elliptical shape with very well delimited borders, occupied up to $6 \mathrm{~m}^{2}$, and presented less than 110 aerial stems (A.A.B. Rossi, unpublished data). Excavations revealed that nearby aerial stems within a cluster are attached frequently by horizontal, subterranean stems and that adventitious buds located in roots and subterranean stems play a key role in promoting horizontal spread of the cluster via vegetative propagation (L.O. Oliveira, unpublished data).

Psychotria ipecacuanha presents distyly (Assis \& Giulietti 1999), as do several other species of this genus. Although the literature does not mention the presence of an incompatibility system and reciprocal herkogamy in $P$. ipecacuanha these characteristics are often associated with distyly (Barrett 1998).

In the present study we examined the variation in floral traits and the incompatibility system in three natural populations of $P$. ipecacuanha from the Atlantic Forest and addressed the following questions: 1) What are the frequencies of floral morphs in natural populations? 2) Is reciprocal herkogamy present? 3) Which floral traits can discriminate the two floral morphs? 4) Can floral traits from a given morph vary among populations? 5) Does the species exhibit any incompatibility system?

\section{Material and methods}

Sites and studied populations - Psychotria ipecacuanha (Brot.) Stokes are perennial, 0.2-0.5 m tall subshrubs that exhibit very slow growth. The inflorescence is terminal. The flowers are sessile, 12-150 per inflorescence, displaying cream or whitish color, rarely bluish, heterostylous, with a bicarpellate, bilocular ovary with a single ovule per locus, 
and basal placentation (Assis \& Giulietti 1999). The species lacks studies about pollinator visitation. However, field observations showed that the flowers of P. ipecacuanha were visited frequently and exclusively by flies (family Sepsidae) (L.O. Oliveira, unpublished data), which may act as pollinators.

Field examination and sampling of plant material for laboratory analyses were carried out in clusters of three natural populations. Two of these populations are located within the Rio Doce State Park (PERD), Minas Gerais state, and are separated by at least $40 \mathrm{~km}$. The third population is located in Raposo, Itaperuna, RJ. The distance between PERD and Raposo is about $160 \mathrm{~km}$. We choose these three populations because they possess the largest number of clusters among all the populations we have located in southeastern Brazil (Oliveira \& Martins 2002), therefore allowing statistical comparisons within and among populations. Vouchers specimens were collected from each study population and deposited in the VIC Herbarium (Federal University of Viçosa).

PERD is located in the "Vale do Aço" region (about 300 m elevation; between $42^{\circ} 32^{\prime} 30^{\prime \prime}$ and $48^{\circ} 28^{\prime} 18^{\prime \prime} \mathrm{W}$ and $19^{\circ} 48^{\prime} 18^{\prime \prime}$ and $19^{\circ} 29^{\prime} 24^{\prime \prime} \mathrm{S}$ ) within the municipalities of Timóteo, Marliéria and Dionísio, at the convergence of rivers Piracicaba and Doce. The climate is Aw, according to the classification of Köppen, that is, hot subhumid with a raining season in the summer and a dry season in the winter (IEF 1994). The annual average temperature for PERD varies from 21 to $24^{\circ} \mathrm{C}$. July is the month with the lowest mean temperature $\left(19.5^{\circ} \mathrm{C}\right)$, while February is the month with the highest mean temperature $\left(25.5^{\circ} \mathrm{C}\right)$. Annual rainfall ranged from 700 to $1,200 \mathrm{~mm}$ (EPAMIG 1978). The vegetation is classified as "Floresta Estacional Semidecidual Submontana", according to the phytogeographic system proposed by Veloso et al. (1991). We named the two populations located within PERD after the sites where they have been found: Trilha do Vinhático (TVI) and Trilha da Lagoa do Meio (TLM). TVI, with 10 clusters, is located in the understory of a secondary forest that display a high, dense canopy. Although this site is well conserved at the moment, its vegetation developed after a fire that took place in the 60's. TLM, with 12 clusters, is located under a primary forest with no record of being subjected to either fires or anthropic disturbances.

Raposo (190 m elevation; 21 ${ }^{\circ} 07^{\prime} \mathrm{S}$ and $42^{\circ} 06^{\prime} \mathrm{W}$ ) has vegetation classified as "Floresta Estacional Semidecidual" (IBGE 1993). The climate is characterized by the presence of two well defined seasons, a raining season in the summer and a dry season in the winter. Average annual temperature is about $22^{\circ} \mathrm{C}$. The Raposo population (RAP), with 13 clusters, is located in the understory of a secondary forest within a private property. It exhibits a tall, dense forest canopy that is free from logging and is protected from cattle grazing.

Morphology and floral biology - The 35 clusters were visited throughout the reproductive seasons of 2001/2002 and 2002/2003. Flowering in P. ipecacuanha is gradual. Typically, an inflorescence displays one to four, more often two, open flowers on a given day. Opening starts at the center of the inflorescence and proceeds to the periphery. We inspected the morph present in inflorescences of every flowering stem in every cluster. These examinations intended to investigate whether distinct floral morphs, and therefore distinct genets, could co-exist within a given cluster. Inflorescences for morphology studies were collected during visits in November and December 2002. At that time, we sampled three to six inflorescences per cluster. In order to be sampled, an inflorescence should exhibit at least one open flower and at least one flower bud in pre-anthesis stage. The plant material was kept in $70 \%$ ethanol and pollen grains kept in glacial acetic acid (Louveaux et al. 1978) until further use.

Morphometric analyses were carried out in 90 shortstyled flowers (TVI, $\mathrm{n}=25$; TLM, $\mathrm{n}=33$; and RAP, $\mathrm{n}=32$ ) and 78 long-styled flowers (TVI, $\mathrm{n}=27$; TLM, $\mathrm{n}=31$; and $\mathrm{RAP}, \mathrm{n}=20$ ). These analyses included at least three flowers of each inflorescence (up to a maximum of seven). Each flower was observed individually under a stereomicroscope. At that time, the corolla tube diameter (TD) was recorded. Subsequently, the corolla was slit longitudinally and subjected to morphometric evaluation. As depicted in figure 1A, the top of the nectar disc was taken as a reference to obtain the following measurements: corolla length (CL), corolla tube length (TL), anther height (AH), stigma height (SH), stigma length (SL), and anther length (AL).

Pollen grains from flower buds in pre-anthesis stage were acetolyzed according to the method of Erdtman (Louveaux et al. 1978). Our analysis used five to seven pollen grains per bud, which had been each sampled from a distinct cluster. Overall, we analyzed pollen grains from 30 clusters: 17 short-styled clusters (RAP, $\mathrm{n}=6$; TVI, $\mathrm{n}=5$; and TLM, $n=6$ ) and 13 long-styled clusters (RAP, $n=4$; TVI, $n=4$; and TLM, $n=5$ ). The pollen grains were observed through an Olympus AX70 microscope and their image recorded using the software Imagem-pro plus. We measured the diameter of 102 pollen grains from short-styled clusters (RAP, $n=34$; TVI, $\mathrm{n}=30$; and TLM, $\mathrm{n}=38$ ) and 77 pollen grains from longstyled clusters (RAP, $n=22 ; T V I, n=25 ; T L M, ~ n=30)$. The number of pollen grains produced in anthers of each floral morph was estimated according to Cruden (1977). Initially, we choose at random 10 clusters of each floral morph and sampled one flower bud from each cluster. We then selected randomly a single anther from each bud. Finally, we counted all of the pollen grains in each anther and estimated the mean number of pollen grains per anther in each floral morph.

We also recorded the time of anthesis, pollen availability, and duration of the flower. Presence of osmophores was tested using neutral red in aqueous solution (Dafni 1992). Several flowers were isolated in glass vials and used to test the presence of scent. Pollen viability was assessed using the aceto-carmine staining technique (Radford et al. 1974). Stigma receptivity was tested by $\mathrm{H}_{2} \mathrm{O}_{2}$ reaction (Zeisler 1938).

Statistical analyses used ANOVA and t student test (Neter \& Wasserman 1974) to compare traits of floral morphs within populations. Correlation coefficients within each floral 
morph were obtained for stigma height and anther height with the remaining floral traits. Statistical analyses were conducted in Statistica version 5.5 (StatSoft 2000).

Incompatibility system - We performed a series of hand pollination treatments in field conditions to characterize the incompatibility system of $P$. ipecacuanha. Hand pollinations were performed using long- and short-styled flowers from populations TVI and TLM during November and December 2002. Inflorescences containing flower in pre-anthesis were enclosed in fine-mesh organza bags, a system designed to prevent flower visitation by flies (Sepsidae) or other insects. According to the methods proposed by Bawa \& Beach (1983) and Dafni (1992), we applied the following six treatments: 1) Spontaneous self-pollination - Inflorescences containing flower buds were marked with labels and the whole inflorescence was enclosed; 2) Hand self-pollination - flowers received self pollen; 3) Legitimate pollination - flowers that had been previously emasculated received pollen from an individual of a different morph; 4) Illegitimate pollination flowers that had been previously emasculated received pollen from a different individual of the same morph; 5) Agamospermy - flower buds were emasculated before enclosing; 6) Open pollination - flower buds were left untouched to assess natural pollination. With the exception of the latter treatment, all flowers were bagged after each treatment and kept enclosed until floral senescence had been completed. Tagged individual were observed fortnightly and fruit-set success was determined 45 days after the treatments.

We also examined the penetration of pollen tube into styles from flowers that had been hand pollinated (self, legitimate, and illegitimate pollinations). About 12 and $24 \mathrm{~h}$ after the treatment, the flowers were collected and kept in $70 \%$ ethanol. Subsequently, the pistils in each flower were examined via fluorescence microscopy (Olympus AX70), according to the method of Martin (1959).

\section{Results}

Isomorphic clusters and isoplethic populations-Assessment of the floral morphs showed that the clusters of $P$. ipecacuanha exhibited either short-styled or longstyled flowers (figure 1B, 1C). The co-existence of both morphs in the same cluster was not observed in any of the three populations, that is, the clusters of $P$. ipecacuanha are isomorphic. The ratio of short-styled to long-styled clusters in each population was 7:6 (RAP), 5:5 (TVI), and 6:6 (TLM). Therefore, these populations display equilibrium morph ratio of $1: 1$, that is, they present isoplethy.

Presence of reciprocal herkogamy - Stigma and anthers are reciprocally placed in each floral morph, as demonstrated by the mean values we obtained for these two traits (table 1). Figure 2 shows the distribution of values for stigma height and anther height in each population. None of three populations we investigated exhibited intermediate values for these two traits, as one would expect for a heterostylous species. In shortstyled morph, stigma height varied from 2.9 to $4.7 \mathrm{~cm}$ and anther height ranged from 4.8 to $8.7 \mathrm{~cm}$. In longstyled morph, stigma height varied from 5.4 to 8.9 and anther height varied from 3.0 to $5.0 \mathrm{~cm}$. In both morphs, however, flower morphology is such that either the stigma in the long-styled morph or the anthers in shortstyled morphs are located above the top of the corolla. In this regard, in every population, the mean corolla tube length was shorter than the mean stigma height in longstyled morph and shorter than the mean anther height in the short-styled morph (table 1).
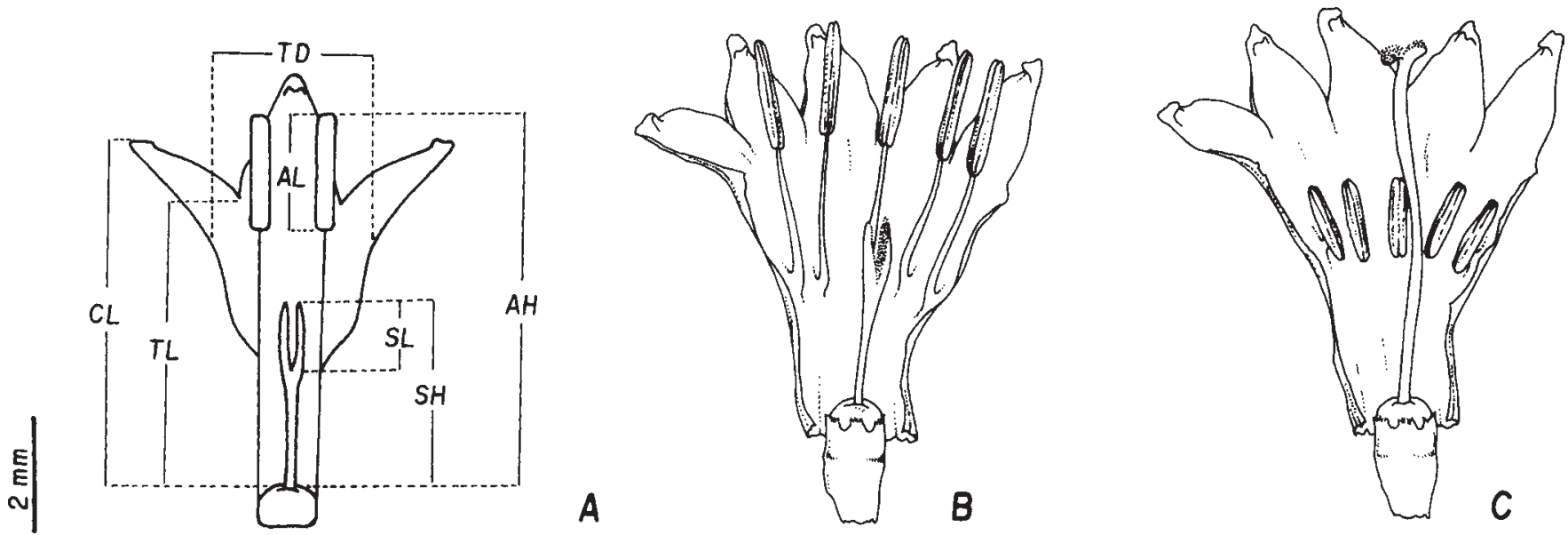

Figure 1. Flowers of Psychotria ipecacuanha. A. Floral diagram $(\mathrm{CL}=$ corolla length, $\mathrm{TL}=$ corolla tube length, $\mathrm{AH}=\mathrm{anther}$ height, $\mathrm{SH}=$ stigma height, $\mathrm{SL}=$ stigma length, $\mathrm{AL}=$ anther length, TD = corolla tube diameter). B. Short-styled morph. C. Longstyled morph. 
Table 1. Floral dimensions (mean $\pm \mathrm{SD}$, in $\mathrm{mm}$ ) for plants of the short-styled (S) and long-styled (L) morph in three natural populations (RAP, TVI, and TLM) of Psychotria ipecacuanha $\mathrm{N}=$ number of flowers, $\mathrm{SH}=$ stigma height; $\mathrm{AH}=$ anther height, $\mathrm{AL}=$ anther length; $\mathrm{SL}=$ stigma length; $\mathrm{CL}=$ corolla length; $\mathrm{TL}=$ corolla tube length; and $\mathrm{CD}=$ corolla diameter. $\mathrm{t}=\mathrm{value}$ of Student test, and $\mathrm{F}=$ value of $\operatorname{ANOVA}(* * \mathrm{p}<0.01, * \mathrm{p}<0.05$, and $\mathrm{NS}=$ nonsignificant at $5 \%)$.

\begin{tabular}{|c|c|c|c|c|c|c|c|c|c|}
\hline Population & $\mathrm{N}$ & & SH & $\mathrm{AH}$ & $\mathrm{AL}$ & SL & CL & TL & $\mathrm{CD}$ \\
\hline \multirow{3}{*}{ RAP } & 32 & $\mathrm{~S}$ & $3.2 \pm 0.6$ & $6.2 \pm 0.6$ & $2.2 \pm 0.2$ & $1.5 \pm 0.2$ & $7.2 \pm 0.8$ & $5.2 \pm 0.6$ & $3.2 \pm 0.4$ \\
\hline & 20 & $\mathrm{~L}$ & $7.1 \pm 0.3$ & $3.4 \pm 0.1$ & $1.6 \pm 0.1$ & $0.9 \pm 0.1$ & $6.9 \pm 0.3$ & $4.9 \pm 0.2$ & $3.0 \pm 0.2$ \\
\hline & & $\mathrm{t}$ & $30.0 * *$ & $24.1 * *$ & $13.3^{* *}$ & $15.4^{* *}$ & $1.5^{\mathrm{NS}}$ & $3.8^{* *}$ & $2.7 * *$ \\
\hline \multirow[t]{3}{*}{ TVI } & 25 & $\mathrm{~S}$ & $3.8 \pm 0.6$ & $7.1 \pm 0.7$ & $2.1 \pm 0.2$ & $1.8 \pm 0.2$ & $7.8 \pm 0.7$ & $5.6 \pm 0.4$ & $3.9 \pm 0.2$ \\
\hline & 27 & $\mathrm{~L}$ & $7.3 \pm 0.8$ & $3.9 \pm 0.4$ & $1.7 \pm 0.1$ & $1.0 \pm 0.3$ & $7.3 \pm 0.6$ & $5.2 \pm 0.4$ & $3.3 \pm 0.2$ \\
\hline & & $\mathrm{t}$ & $14.7 * *$ & $23.9 * *$ & $9.3^{* *}$ & $10.7^{* *}$ & $3.7 * *$ & $3.4 * *$ & $16.5^{* *}$ \\
\hline \multirow[t]{3}{*}{ TLM } & 33 & $\mathrm{~S}$ & $3.2 \pm 0.5$ & $6.4 \pm 0.7$ & $2.1 \pm 0.1$ & $1.7 \pm 0.2$ & $7.0 \pm 0.5$ & $5.1 \pm 0.4$ & $3.5 \pm 0.4$ \\
\hline & 31 & $\mathrm{~L}$ & $7.2 \pm 0.8$ & $3.9 \pm 0.4$ & $1.8 \pm 0.1$ & $1.2 \pm 0.3$ & $7.3 \pm 0.8$ & $5.3 \pm 0.5$ & $3.1 \pm 0.4$ \\
\hline & & $\mathrm{t}$ & $23.6^{* *}$ & $15.3 * *$ & $8.1 * *$ & $9.3^{* *}$ & $1.8^{\mathrm{NS}}$ & $1.9^{\mathrm{NS}}$ & $3.9^{* *}$ \\
\hline \multirow[t]{2}{*}{$\mathrm{F}$} & & S & $12.1 * *$ & $16.4^{* *}$ & $4.6^{*}$ & $25.3 * *$ & $14.9 * *$ & $11.0 * *$ & $30.1 * *$ \\
\hline & & $\mathrm{L}$ & $0.7^{\mathrm{NS}}$ & $19.6 * *$ & $47.5^{* *}$ & $13.6^{* *}$ & $2.9^{\mathrm{NS}}$ & $12.1 * *$ & $10.3 * *$ \\
\hline
\end{tabular}

A Discrimination between morphs - Table 1 shows the

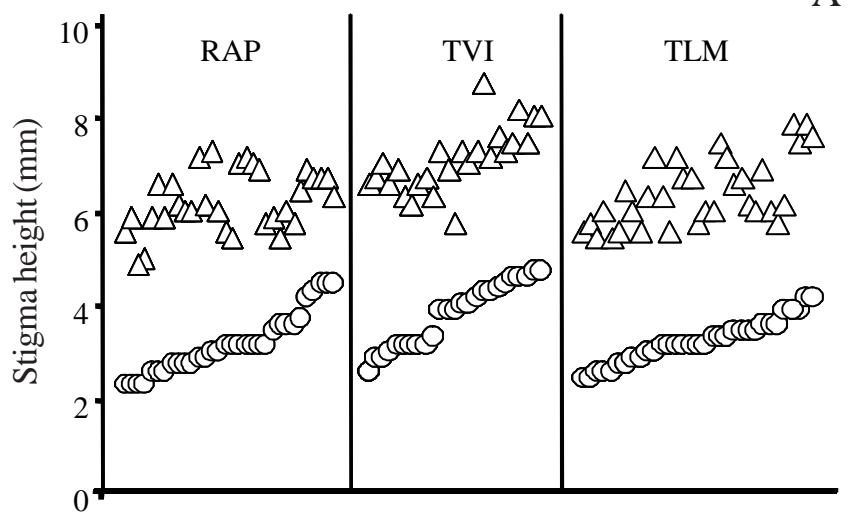
mean values $( \pm S D)$ and the results of the $t$ test for the morphometric analyses of all floral traits. There were significant differences $(\mathrm{p}<0.05)$ between morphs in each population for anther length, stigma length, and corolla tube diameter. However, corolla length didn't differ significantly between the two morphs in populations RAP and TLM. Likewise, there was no significant difference between morphs in population TLM for corolla tube length. Correlation studies (table 2) showed that stigma height and anther height were positively associated with most of the floral traits we investigated.

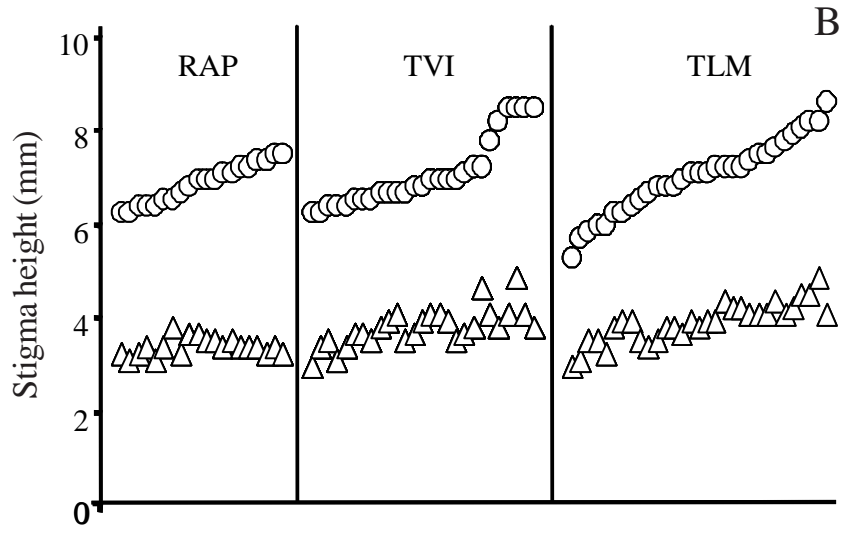

Figure 2. Range of variation in stigma and anther height in three natural populations (RAP, TVI, and TLM) of Psychotria ipecacuanha. A. Short-styled morph (RAP, $\mathrm{n}=32$; TVI, $\mathrm{n}=25$; and TLM, $\mathrm{n}=33$ ). B. Long-styled morph (RAP, $\mathrm{n}=20$; TVI, $\mathrm{n}=27$; and TLM, $\mathrm{n}=31$ ). Circles and triangles represent stigmas and anthers, respectively. Individual flowers in each population were ordered according to stigma height.
The only exceptions were anther length in short-styled morph and anther and stigma length in long-styled morph, for which no significant correlations were found.

Pollen grains of the short-styled morph have a larger diameter than those of the long-styled morph, regardless of the population investigated (figure 3 ). However, results of the $t$ test $(n=10 ; t=19.83 ; p<0.001)$ showed that anther of the short-styled morph produces significantly fewer pollen grains $(647 \pm 10.6$; mean \pm SD) when compared to anther of the long-styled morph (748 \pm 11.9 ; mean $\pm \mathrm{SD}$ ). As shown in table 1, anther length was significantly larger in short-styled morph in each of the three populations. Interestingly, the increase in pollen size is accompanied by an increase in anther length.

Anthesis took place between 7:00 to 8:00 h, regardless of the floral morph. Flowers started to show senescence about 22 to 24 hours after anthesis. No differences between morphs were observed in the following attributes: stigma receptivity (receptive from 
Table 2. Correlation coefficients for floral traits measured on short-styled ( $\mathrm{n}=90)$ and long-styled $(\mathrm{n}=78)$ morphs of Psychotria ipecacuanha. $\mathrm{SH}=$ stigma height; $\mathrm{AH}=$ anther height; $\mathrm{AL}=$ anther length; $\mathrm{SL}=$ stigma length; $\mathrm{CL}=$ corolla length; $\mathrm{TL}=$ corolla tube length; and $\mathrm{CD}=$ corolla diameter $(* * \mathrm{p}<0.01)$.

\begin{tabular}{|c|c|c|c|c|}
\hline & \multicolumn{2}{|c|}{ Short-styled morph } & \multicolumn{2}{|c|}{ Long-styled morph } \\
\hline & SH & $\mathrm{AH}$ & SH & $\mathrm{AH}$ \\
\hline $\mathrm{AH}$ & $0.6 * *$ & & $0.6^{* *}$ & \\
\hline $\mathrm{AL}$ & 0.0 & $0.3^{* *}$ & 0.2 & 0.3 \\
\hline SL & $0.6^{* *}$ & $0.5^{* *}$ & -0.1 & -0.0 \\
\hline $\mathrm{CL}$ & $0.7 * *$ & $0.8^{* *}$ & $0.7 * *$ & $0.8 * *$ \\
\hline $\mathrm{TL}$ & $0.7 * *$ & $0.7 * *$ & $0.7 * *$ & $0.8 * *$ \\
\hline $\mathrm{CD}$ & $0.4 * *$ & $0.5^{* *}$ & $0.4 * *$ & $0.3^{* *}$ \\
\hline
\end{tabular}

anthesis to senescence), pollen availability (always available), osmophores (present at the corolla lobules), and perceptible scent (absent in both morphs). There was a significant difference between morphs for pollen viability $(\mathrm{n}=18 ; \mathrm{t}=2.62 ; \mathrm{p}=0.0178)$. Pollen viability in the short-styled morph reached $94.2 \pm 3.1 \%$ (mean $\pm \mathrm{SD}$ ), while that of the long-styled morph reached $96.6 \pm 1.9 \%$ (mean $\pm \mathrm{SD})$.

Variation among populations - The attributes of floral morphology were compared within morph among populations and the results of the ANOVA are summarized in table 1 . There were significant morphological differences among the three populations

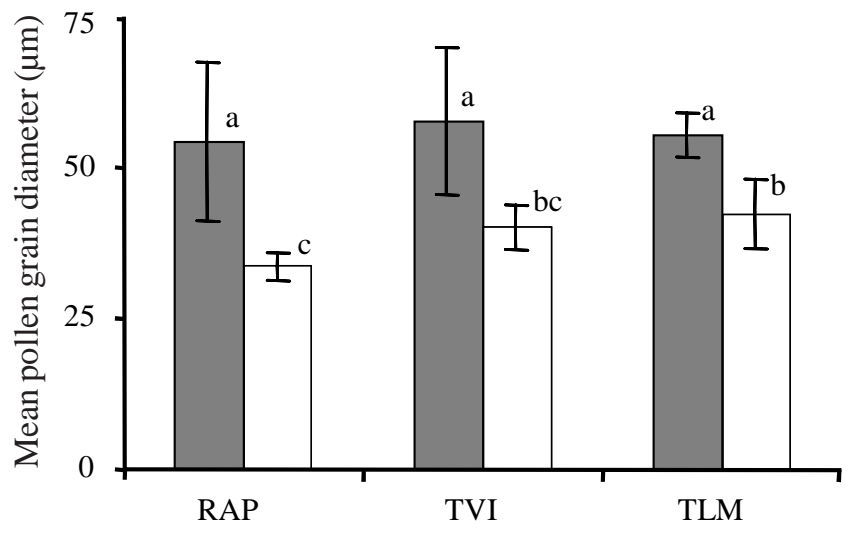

Figure 3. Mean pollen grain diameter in three natural populations (RAP, TVI, and TLM) of Psychotria ipecacuanha. Dark columns = short-styled morph (RAP, $\mathrm{n}=34$; TVI, $\mathrm{n}=30$; and TLM, $\mathrm{n}=38$ ); white columns = longstyled morph (RAP, $\mathrm{n}=22$; TVI, $\mathrm{n}=25$; TLM, $\mathrm{n}=30$ ). Columns with the same letters do not differ significantly (Tukey test, $\mathrm{p}<0.05)$. Vertical lines show standard deviations. for all seven floral traits regarding the short-styled morph. Nevertheless, there were no significant differences among populations for stigma height within the long-styled morph. As shown in figure 4, there is significant difference among populations in pollen grain size within the long-styled morph but none within the short-styled morph.

Incomplete self-incompatibility - With the exception of hand self-pollination, all treatments resulted in fruit production (table 3 ) and fruit development did not differ markedly among treatments. However, seed viability was not tested. Following legitimate pollination, plants of the short-styled morph produced $40 \%$ fruit set while plants of the long-styled morph produced $51.8 \%$ fruit set. Illegitimate pollination resulted in $6.7 \%$ fruit set in the short-styled morph and $20.8 \%$ fruit set in the long-styled morph and therefore suggested that some degree of within-morph compatibility is present in P. ipecacuanha. Observation of pollen tube penetration into styles, via fluorescence microscopy, revealed the presence of a larger number of tubes after legitimate pollination. Moreover, these tubes exhibited growth more regular when compared to those obtained after illegitimate pollination (data not-shown). Pollen tubes in pistils of legitimate-pollinated flowers were able to reached the base of the style and, in some cases, the ovary $12 \mathrm{~h}$ after pollination. In contrast, after illegitimate pollination, pollen tubes presented irregular growth, developed only until the first third of the style and reached the base of the style on rare occasions.

Table 3. Results of pollination experiments on short-styled (S) and long-styled (L) morphs of Psychotria ipecacuanha in natural population conditions. $\mathrm{N}=$ number of flowers; $\mathrm{FS}=$ Fruit set.

\begin{tabular}{clcc}
\hline Floral morph & Pollination & N & FS $(\%)$ \\
\hline \multirow{2}{*}{ S } & Spontaneous self & 30 & 3.3 \\
& Hand self & 20 & 0.0 \\
& Legitimate & 25 & 40.0 \\
& Illegitimate & 31 & 6.7 \\
& Agamospermy & 30 & 3.3 \\
& Open & 30 & 16.7 \\
L & Spontaneous self & 28 & 7.1 \\
& Hand self & 24 & 0.0 \\
& Legitimate & 27 & 51.8 \\
& Illegitimate & 24 & 20.8 \\
& Agamospermy & 28 & 10.7 \\
& Open & 32 & 25.0 \\
\hline
\end{tabular}




\section{Discussion}

Psychotria ipecacuanha exhibit isomorphic clusters, that is, the clusters present only one of the two floral morphs. This isomorphy is an attribute that probably is associated with the perennial habit and the vegetative propagation shown by this species. Our results indicate that homostylous morphs are not present in $P$. ipecacuanha and, therefore, the stigma and anthers can never occupy the same position within a given flower. As proposed by Ganders (1979) and Lloyd \& Webb (1992), this spatial architecture characterizes reciprocal herkogamy, and therefore $P$. ipecacuanha can be considered a true distylous species. Populations of $P$. ipecacuanha exhibit isoplethy, that is, they possess an equilibrium morph ratio of 1:1 between long-styled and short-styled clusters. Such isoplethic rate suggests that the two morphs of $P$. ipecacuanha possess equal fitness. However, it should be noted that our investigation deduced isoplethy based upon the ratio of long-styled to short styled clusters only, and does not exclude the possibility that the two morphs may differ in other attributes of vegetative propagation, such as cluster size, number of flowers per aerial stem, or number of aerial stem per cluster.

When compared between morphs, the stigmas may differ in overall shape, size, or more frequently, in the size of the stigmatic papillae (Ganders 1979). In species that exhibits heteromorphic self-incompatibility, the stigma has typically a larger size in the long-styled morph, although the opposite has been reported for other groups (Dulberger 1992). Our data conforms to the opposite trend, because in P. ipecacuanha the short-styled morph presented larger stigmas. Our results are similar to those reported in Palicourea fendleri Standl. and P. petiolaris Kunth (Sobrevila et al. 1983) and in the congeneric species Psychotria jasminoides Standl., P. pubigera Schlecht., and P. nuda Wawra (Castro \& Araújo 2004).

In several distylous Rubiaceae, plants of the shortstyled morph have significantly larger corollas, as recorded in Palicourea fendleri and P. petiolaris (Sobrevila et al. 1983), Guettarda scabra Lam. (Richards \& Koptur 1993), Gaertnera vaginata Lam. (Pailler \& Thompson 1997) and Palicourea padifolia (Willdenow ex Roemer \& Schultes) C.M. Taylor \& D.Lorence (Ree 1997). This association cannot be generalized for all Rubiaceae because there are species for which larger corollas are found in plants of the shortstyled morph (Stone 1995). Moreover, corolla length may not differ between floral morphs, as reported in several
Psychotria species: P. jasminoides, P. birotula L.B.Sm. \& Downs, and P. pubigera (Castro \& Oliveira 2002) and P. barbiflora DC. (Monteiro et al. 1991). These preceding studies, however, did not investigate the possibility that floral traits may present variation when compared among populations. In this regard, our results showed that the two morphs of $P$. ipecacuanha differ significantly in corolla length when compared within one population (TVI), but not within each of the remaining two populations (RAP and TLM). Although our results have shown that corolla length may vary among populations, the actual contribution of this variation for the reproductive success of each population is nevertheless uncertain. The increase in pollen size accompanied by an increase in anther size in short styled-morph, as we observed in P. ipecacuanha, is an association that has been reported in several other distylous species (Dulberger 1992, Pailler \& Thompson 1997).

The pollen size dimorphism in $P$. ipecacuanha is characterized by pollen grains from short-styled morph being larger than those from long-styled morph. However, pollen grains in long-styled morph outnumbered those produced by the short-styled morph. In this sense, pollen grain size and number in $P$. ipecacuanha are comparable to those found in other distylous species (Dulberger 1992) and in other Rubiaceae, as in Gaertnera vaginata (Pailler \& Thompson 1997), Psychotria barbiflora (Monteiro et al. 1991), and Palicourea padifolia (Ree 1997). The larger number of pollen grains produced by anthers of the long-styled morph, as seen in P. ipecacuanha, may play an important compensatory role during pollination, since stigmas of the long-styled morph usually receive a larger load of pollen grains when compared to stigmas of the short-styled morph (Lloyd \& Webb 1992).

The pollen grains of $P$. ipecacuanha exhibit a reciprocal variation in shape and size between morphs. According to Richards (1986), the smaller pollen grains produced by the long-styled morph are better fit to accommodate within the small space that exists among stigmatic papillae of the short-styled morph and, reciprocally, the larger pollen grains from short-styled morph are better fit to accommodate within the larger space found among stigmatic papillae of the long-styled morph. Although our study did not evaluate the size of stigmatic papillae, chances are that the remark above is also valid in $P$. ipecacuanha.

Fruit set in $P$. ipecacuanha was greater after legitimate pollination, a result comparable to those observed in most distylous species (Barrett 1992). Fruit 
set in both morphs was much greater after legitimate pollination than after open pollination. This result indicates that deficient pollination service may limit fruit production in $P$. ipecacuanha. Similar low fruit production in natural populations has been documented in many species and the proximate causes attributed to several factors, including the lack of pollinators (Bertin 1982) or interference by self or genetically related pollen (Ramsey \& Vaughton 2000).

A consequence of the presence of a typical heteromorphic incompatibility system in a distylous species is that only legitimate pollination results in fruit production. However, the literature reports the existence of several types of variation in the typical system. Some of these variant systems are reported in Rubiaceae. Selfand within-morph compatibility was reported in Palicourea padifolia (Ree 1997) and in Psychotria jasminoides (Castro \& Oliveira 2002). Low fruit set following self- and illegitimate pollination was also observed by several authors (Bawa \& Beach 1983, Sobrevila et al. 1983, Barrett \& Shore 1987, Castro \& Araújo 2004), which suggest that the heteromorphic incompatibility system of some heterostylous Rubiaceae is not strict. Indeed, our experimental pollinations demonstrated that the heteromorphic incompatibility system of $P$. ipecacuanha admits some degree of selfand within-morph compatibility. Fruit set varied between the two morphs after self- and illegitimate pollination, with more fruits being produced by long-styled morph than by short-styled morph. It is important to notice that seed viability was not assessed and, therefore, selfsterility cannot be ruled out at this point.

The degree of compatibility is associated to many factors, including floral morphology and abundance of pollinators (Barrett 1988). According to the hypothesis proposed by Ornduff (1970), the joint actions of the morphological and physiological incompatibilities, associated to heterostyly, have implications in the reproduction of wild populations, such as those of $P$. ipecacuanha. The mechanism of morphological incompatibility would promote an increase in the number of legitimate pollination between compatible genotypes. On the other hand, the mechanism of physiological incompatibility would promote cross-pollination, which would result in the maintenance of heterozygosity in the population and species gene pool. Subsequent studies are necessary to confirm intra-morph compatibility and to investigate further the role it plays in the sexual reproduction of $P$. ipecacuanha.

According to Richards (1986), agamospermy is a strategy used to achieve reproduction in the absence of pollinators. Fruit production after agamospermy suggests the possibility that this strategy is used by P. ipecacuanha. Although infrequent in Rubiaceae, agamospermy has been recorded in other congeneric species, such as Psychotria birotula and P. nuda (Castro \& Araújo 2004, Castro \& Oliveira 2002). However, the floral arrangement exhibited by $P$. ipecacuanha makes the isolation of a flower bud difficult and there is a possibility that pollen grains may have fallen into stigmas during flower manipulation. Likewise in natural and intramorph fruit-set, it is important to notice that seed viability as not tested and fruit-like galling processes could not be ruled out either.

In conclusion, this investigation demonstrated that clusters of $P$. ipecacuanha in natural populations exhibit isomorphy (presence of a single floral morph) and that populations present an equilibrium ratio between floral morphs (isoplethy). Long- and short-styled morphs differ in stigma height, anther height, stigma length, number of pollen grains per anther, and mean diameter of the pollen grain. The species present the necessary reciprocal herkogamy to be considered truely distylous and there are morphological differences among populations within each floral morph. The species shows some degree of intramorph compatibility, even though fruit set was much greater following legitimate pollinations.

Acknowledgments - The authors thanks the International Foundation for Science for the financial support for this study (Grant No D/2815-1 to L.O.O.) and the "Instituto Estatual de Florestas" for the permits to collect in the Rio Doce State Park. The first author thanks Unemat and Capes for providing a fellowship and Osvaldo S. Rossi, Sergio S. da Silva, and Lourdes Iarema for assistance during field trips. Thanks also go to two anonymous reviewers for comments, which helped in improving an earlier version of this manuscript.

\section{References}

ASSIS, M.C. \& GIULIETTI, A.M. 1999. Diferenciação morfológica e anatômica em populações de "ipecacuanha" - Psychotria ipecacuanha (Brot.) Stokes (Rubiaceae). Revista Brasileira de Botânica 22:205-216.

BARRET, S.C.H. 1988. The evolution, maintenance and loss of self-incompatibility system. In Plant reproductive ecology: patterns and strategies (J. Lovett-Doust \& L. Lovett-Doust, eds.). Oxford University Press, Oxford, p.98-123.

BARRET, S.C.H. 1992. Heterostylous genetic polymorphisms: model systems for evolutionary analysis. In Evolution and function of heterostyly (S.C.H. Barret, ed.) Monographs on theoretical and applied genetics. Springer-Verlag, Berlin, p.1-29. 
BARRET, S.C.H. 1998. The evolution of mating strategies in flowering plants. Plant Science 9:335-341.

BARRET, S.C.H. \& SHORE, J.S. 1987. Variation and evolution of breeding systems in the Turnera ulmifolia L. complex (Turneraceae). Evolution 41:340-354.

BAWA, K.S. \& BEACH, J.H. 1983. Self-incompatibility systems in the Rubiaceae of a tropical lowland wet forest. American Journal of Botany 70:1281-1288.

BERTIN, R.I. 1982. Floral biology, hummingbird pollination and fruit production of trumpet creeper Campsis radicans (Bignoniaceae). American Journal of Botany 69:123-134.

BRUNETON, J. 1995. Pharmacognosy, Phytochemistry, Medicinal Plants. Lavoisier, Paris.

CASTRO, C.C. \& ARAÚJO, A.C. 2004. Distyly and sequential pollinators of Psychotria nuda (Rubiaceae) in the Atlantic rain forest, Brazil. Plant Systematic and Evolution 244:131-139.

CASTRO, C.C. \& OLIVEIRA, P.E. 2002. Pollination Biology of Distylous Rubiaceae in the Atlantic Rain Forest, SE Brazil. Plant Biology 5:640-646.

CRUDEN, R.W. 1977. Pollen-ovule rations: A conservative indicator of breeding systems in flowering plants. Evolution 31:32-46.

DAFNI, A. 1992. Pollination Ecology. A practical approach. Oxford University Press, New York.

DULBERGER, R. 1992. Floral polymorphisms and their functional significance in the heterostylous syndrome. In Evolution and function of heterostyly (S.C.H. Barret, ed.) Monographs on theoretical and applied genetics. Springer-Verlag, Berlin, p.41-84.

EPAMIG. 1978. Leguminosas nativas do Estado de Minas Gerais: coletas e avaliações preliminares de alguns gêneros. Empresa de Pesquisa Agropecuária de Minas Gerais, Belo Horizonte.

FAIVRE, A.E. \& MCDADE, L.A. 2001. Population-level variation in the expression of heterostyly in three species of Rubiaceae: does reciprocal placement of anthers and stigmas characterize heterostyly? American Journal of Botany 88:841-853.

GANDERS, F.R. 1979. The biology of heterostyly. New Zealand Journal of Botany 17:607-635.

IBGE. 1993. Mapa da vegetação do Brasil. Fundação Instituto Brasileiro de Geografia e Estatística, Brasília.

IEF. 1994. Pesquisas prioritárias para o Parque Estadual do Rio Doce, Brasil. Instituto Estadual de Florestas, Belo Horizonte.

LLOYD, D.G. \& WEBB, C.J. 1992. The selection of heterostyly. In Evolution and function of heterostyly (S.C.H. Barret, ed.) Monographs on theoretical and applied genetics. Springer-Verlag, Berlin, p.179-207.

LOUVEAUX, J., MAURIZIO, A. \& VORWOHE, G. 1978. Methods of melissopalinology. Bee World 59:139-157.

MARTIN, F.W. 1959. Staining and observing pollen tubes in style by means of fluorescence. Stain Technology 34:125-128.
MENDONÇA, M.P. \& LINS, L.V. 2000.Lista vermelha das espécies ameaçadas de extinção da flora de Minas Gerais. Fundação Biodiversitas, Fundação Zôo-Botânica de Belo Horizonte, Belo Horizonte.

MONTEIRO, R., NAKAJIMA, J.N., RIBEIRO, J.E.L.S. \& TOLEDO, J.C. 1991. Morfologia e distribuição espacial das formas heterostílicas de Psychotria barbiflora DC. (Rubiaceae). Naturalia 16:137-146.

NETER, J. \& WASSERMAN, W. 1974. Applied linear statistical models: Regression, analysis of variance, and experimental designs. Richard D. Irwin, Homewood.

OLIVEIRA, L.O. \& MARTINS, E.R. 1998. O desafio das plantas medicinais brasileiras. I - O caso da poaia (Cephaelis ipecacuanha). Universidade Estadual do Norte Fluminense, Campos dos Goytacazes.

OLIVEIRA, L.O. \& MARTINS, E.R. 2002. A quantitative assessment of genetic erosion in ipecac (Psychotria ipecacuanha). Genetic Resources and Crop Evolution 49:607-617.

ORNDUFF, R. 1970. Incompatibility and the pollen economy of Jepsonia parryi. American Journal of Botany 57:1036-1041.

PAILLER, T. \& THOMPSON, J.D. 1997. Distyly and variation in heteromorphic incompatibility in Gaertnera vaginata (Rubiaceae) endemic to La Reunion Island. American Journal of Botany 84:315-327.

RADFORD, A.E., DICKSON, W.C., MASSEY, J.R. \& BELL, C.R. 1974. Vascular Plant Systematics. Harper and Row, New York.

RAMSEY, M. \& VOUGHTON, G. 2000. Pollen quality limits seed set in Burchardia umbellata (Colchicaceae). American Journal of Botany 87:845-852.

REE, R.H. 1997. Pollen flow, fecundity, and the adaptive significance of heterostyly in Palicourea padifolia (Rubiaceae). Biotropica 29:298-308.

RICHARDS, A.J. 1986. Plant breeding systems. George Allen \& Unwin, London.

RICHARDS, J.H. \& KOPTUR, S. 1993. Floral variation and distyly in Guetarda scabra (Rubiaceae). American Journal of Botany 80:31-40.

SOBREVILA, C., RAMIREZ, N. \& DE ENRECH, N. 1983. Reproductive biology of Palicourea fendleri and $P$. petiolaris (Rubiaceae), heterostylous shrubs of a Tropical Cloud Forest in Venezuela. Biotropica 15:161-169.

STATSOFT. 2000. Statistica for Windows, a computer program manual. StatSoft Inc., Tulsa.

STONE, J.L. 1995. Pollen donation patterns in a tropical distylous shrub (Psychotria suerrensis; Rubiaceae). American Journal of Botany 82:1390-1398.

VELOSO, H.P. 1947. As condições ecológicas da Cephaelis ipecacuanha Rich. Memórias do Instituto Oswaldo Cruz 45:361-372.

VELOSO, H.P., RANGELFILHO, A.L.R. \& LIMA, J.C.A. 1991. Classificação da vegetação brasileira, adaptada a um sistema universal. Instituto Brasileiro de Geografia e Estatística, Rio de Janeiro. 
WOLFE, L.M. 2001. Associations among multiple floral polymorphisms in Linum pubescens (Linaceae), a heterostylous plant. International Journal of Plant Science 162:335-342.
ZEISLER, M. 1938. Über die Abgrenzung der eigentlichen Narbenfläche mit Hilfe von Reaktionen. Beihefte zum Botanischen Zentralblatt 58:308-318. 